\title{
Municipal distribution of bladder cancer mortality in Spain: Possible role of mining and industry
}

\author{
Gonzalo Lopez-Abente*1, Nuria Aragones ${ }^{1}$, Rebeca Ramis ${ }^{1}$, \\ Valentin Hernandez-Barrera ${ }^{1}$, Beatriz Perez-Gomez ${ }^{1}$, Antonio Escolar- \\ Pujolar $^{2}$ and Marina Pollan ${ }^{1}$
}

\begin{abstract}
Address: ${ }^{1}$ Environmental and Cancer Epidemiology Unit, National Centre for Epidemiology, Carlos III Institute of Health, Madrid, Spain and ${ }^{2}$ Servicio de Medicina Preventiva, Hospital Universitario Puerta del Mar, Cádiz, Spain

Email: Gonzalo Lopez-Abente* - glabente@isciii.es; Nuria Aragones - naragones@isciii.es; Rebeca Ramis - rramis@isciii.es; Valentin HernandezBarrera - valentin.hernandez@urjc.es; Beatriz Perez-Gomez - bperez@isciii.es; Antonio Escolar-Pujolar - antonio.escolar@uca.es; Marina Pollan - mpollan@isciii.es

* Corresponding author
\end{abstract}

Published: 27 January 2006

BMC Public Health2006, 6:17 doi:10.1 186/1471-2458-6-17
Received: 22 August 2005

Accepted: 27 January 2006

This article is available from: http://www.biomedcentral.com/147I-2458/6/17

(C) 2006Lopez-Abente et al; licensee BioMed Central Ltd.

This is an Open Access article distributed under the terms of the Creative Commons Attribution License (http://creativecommons.org/licenses/by/2.0), which permits unrestricted use, distribution, and reproduction in any medium, provided the original work is properly cited.

\begin{abstract}
Background: Spain shows the highest bladder cancer incidence rates in men among European countries. The most important risk factors are tobacco smoking and occupational exposure to a range of different chemical substances, such as aromatic amines.

Methods: This paper describes the municipal distribution of bladder cancer mortality and attempts to "adjust" this spatial pattern for the prevalence of smokers, using the autoregressive spatial model proposed by Besag, York and Molliè, with relative risk of lung cancer mortality as a surrogate.

Results: It has been possible to compile and ascertain the posterior distribution of relative risk for bladder cancer adjusted for lung cancer mortality, on the basis of a single Bayesian spatial model covering all of Spain's 8077 towns. Maps were plotted depicting smoothed relative risk (RR) estimates, and the distribution of the posterior probability of RR>I by sex. Towns that registered the highest relative risks for both sexes were mostly located in the Provinces of Cadiz, Seville, Huelva, Barcelona and Almería. The highest-risk area in Barcelona Province corresponded to very specific municipal areas in the Bages district, e.g., Suría, Sallent, Balsareny, Manresa and Cardona.

Conclusion: Mining/industrial pollution and the risk entailed in certain occupational exposures could in part be dictating the pattern of municipal bladder cancer mortality in Spain. Population exposure to arsenic is a matter that calls for attention. It would be of great interest if the relationship between the chemical quality of drinking water and the frequency of bladder cancer could be studied.
\end{abstract}

\section{Background}

In a European context, Spain ranks high in terms of bladder cancer mortality $\left(2^{\text {nd }}\right)$ in men, yet in women it figures among the countries with the lowest rates. During 2002, there were 3492 deaths in men and 703 in women due to this tumour, with an age-adjusted mortality rate (European population) of 14.01 in men and 1.78 in women per 100,000 population. Bladder cancer accounted for $6 \%$ 
and $2 \%$ of cancer deaths in men in women, respectively. In Spain, it is the $5^{\text {th }}$ leading cause of cancer-related death in men and the $13^{\text {th }}$ in women, with a sex ratio of $4: 1$. It is estimated that Spain has an average of 14,400 new cases per annum. The most frequent histological type is transitional cell (93\%), followed by squamous cell cancer (2\%) and adenocarcinomas (1\%). The high bladder cancer survival rate ( $75 \%$ at 5 years in men and $70 \%$ in women) [1] means that partial prevalence (cases diagnosed in the last 5 years) is very high, viz., close on 40,000 . This figure is very similar to that for the most frequent tumours, such as colorectal cancer, and thus constitutes an important public health problem here in Spain.

Spatial analysis of health events (spatial epidemiology) is a discipline that, though still in the development phase, is already enjoying a space of its own in the field of health research $[2,3]$. Its ability to suggest and detect the possible sources of heterogeneity (generally of environmental origin) which determine the spatial patterns of incidence and mortality due to different diseases, imbues this tool with great interest in the sphere of epidemiology and public health. Its potential is, moreover, being reinforced by the ever increasing availability of geographically-indexed population mortality and incidence data, together with advances in computation techniques and Geographic Information Systems. These circumstances are favouring the analysis of the geographical distribution of health data with growing levels of disaggregation [3], an area that encompasses the so-called small-area studies.

The main advantages of such small-area studies are: a) better interpretability of results in comparison with largerscale studies; b) less susceptibility to ecological biases; and c) enhanced ability to detect local effects linked to environmental problems, such as industrial pollution [4].

The most important risk factor in bladder cancer is tobacco use, with the risk increasing in proportion to the intensity of smoking habit [5]. This tumour is also associated with occupational exposure to a range of chemical substances, such as 2-naphtilamine, benzidine and 4-aminobiphenyl, used in, among others, textile mills (dyeing and printing), the production of aromatic amines, and the rubber and leather industries [6-8]. Other environmental risk factors have also been described, such as exposure to the chemical elements of drinking water, whether of natural origin or the result of industrial activities, e.g., arsenic [9-13], or alternatively, exposure to compounds derived from water treatment/disinfection (trihalomethanes) [14]. The presence of inorganic arsenic in some foods [1519] and its relationship with bladder cancer and other tumours is also under study $[11,13]$, though low level arsenic exposure is unlikely to explain a substantial excess risk of bladder cancer [20].
It is assumed that the municipal spatial bladder cancer distribution pattern is fundamentally dictated by the prevalence of smokers, at least in men. The approach used in this study is based on the following idea: if it were possible "to extract" the smoking-habit component from municipal maps (confounding effect), the resulting pattern would then reflect the contribution of the remaining risk factors.

This study sought: a) to display maps depicting the municipal distribution of bladder cancer mortality; and b) to obtain the spatial pattern "adjusted" for the prevalence of smokers. Accordingly, on the assumption that lung cancer mortality is directly linked to the prevalence of tobacco smokers, this variable was used as a surrogate of tobacco use.

\section{Methods}

As case source, we used individual death entries for the period 1989-1998 corresponding to bladder cancer (ICD9 code 188) and lung cancer (ICD-9 code 162), broken down by town or city, nationwide. These data were furnished by the National Statistics Institute (Instituto Nacional de Estadística - INE) for the production of a municipal cancer mortality atlas, of which these results form part.

Municipal populations, broken down by age group (18 groups) and sex, were obtained from the 1991 census and 1996 municipal roll. These years correspond to the midpoints of the two quinquennia that comprise the study period (1989-1993 and 1994-1998). The person-years for each five-year period were obtained by multiplying these populations by 5 .

Standardised mortality ratios (SMR) were calculated as the ratio of observed and expected deaths. For the calculation of expected cases, the overall Spanish mortality rates for the above two 5-year periods were multiplied by each town's person-years by age group, sex and quinquennium.

For map plotting purposes, smoothed municipal relative risks (RR) were calculated using the conditional autoregressive model proposed by Besag, York and Molliè (BYM). This model was introduced by Clayton and Kaldor [21], developed by Besag, York and Molliè [22], and subsequently applied in the field of ecological studies [23]. These models are based on fitting Poisson spatial models with observed cases as the dependent variable, expected cases as offset, and two types of random effects terms which take the following into account: a) municipal contiguity (spatial term); and b) municipal heterogeneity.

The models were fitted using Bayesian Markov chain Monte Carlo simulation methods with non-informative 
Table I: Summaries of population and cancer mortality in the 8077 Spanish towns. Spain I989-1998.

\begin{tabular}{|c|c|c|c|c|c|c|c|}
\hline & Total & Mean & Median & Standard deviation & Minimum & Maximum & $\begin{array}{l}\text { No. (\%) of areas with } \\
\text { zero counts }\end{array}$ \\
\hline Population & 39648759 & 4908.85 & 586 & 42430.43 & 5 & 2866850 & $0(0)$ \\
\hline Observed bladder & 34281 & 4.24 & I & 40.77 & 0 & 2543 & $3823(47.3)$ \\
\hline Expected bladder & 34333 & 4.25 & 0.92 & 39.33 & 0.01 & 2721.16 & $0(0)$ \\
\hline Bladder SMRs' & - & 0.76 & 0.39 & 1.19 & 0 & 26.32 & $3823(47)$ \\
\hline Observed lung & $1550 \mid 4$ & 19.19 & 3 & 190.03 & 0 & 12434 & $1905(24.6)$ \\
\hline Expected lung & 155207 & 19.22 & 3.79 & 177.00 & 0.04 & 12243.54 & $0(0)$ \\
\hline Lung SMRs' & - & 0.72 & 0.69 & 0.64 & 0 & 14.82 & $1905(24.6)$ \\
\hline
\end{tabular}

'Descriptive values of the 8077 SMRs

priors [24]. Posterior distributions of relative risk were obtained using WinBugs [25]. The criterion of contiguity used was adjacency of municipal boundaries. Convergence of the simulations was verified using the BOA (Bayesian Output Analysis) R program library [26]. Given the great number of parameters of the models, the convergence analysis was performed on a randomly selected sample of 10 towns and cities, taking 4 strata defined by municipal size. Convergence of the estimators was achieved before 100,000 iterations. For the maps shown, a "burn-in" (iterations discarded to ensure convergence) of 300,000 iterations was performed and the posterior distribution was derived with 5,000.

Thereafter a model was constructed for bladder cancer, similar to the above model but adding, as another fixedeffects term, the posterior distribution of RR for lung cancer normalised by means of its logarithm.

A Geographic Information System was used to plot municipal maps that depicted smoothed RR estimates and the distribution of the posterior probability (pp) that $\mathrm{RR}>1$ (Bayesian version of $\mathrm{p}$ value). With regard to this indicator, we followed Richardson's criterion [4], which recommends that probabilities above 0.8 should be deemed significant.

Separate analyses were performed for men and women.

\section{Results}

From 1989 to 1998 , a total of 34281 bladder cancer deaths were registered in Spain, 28173 in men and 6108 in women. In 3824 towns and cities no death due to this cause was registered. Using these data, an acceptable computation time and conventional computers, it was possible to compile and ascertain the posterior distribution of relative risk on the basis of a single spatial model that included all of Spain's 8077 towns and cities and the 46398 adjacencies existing between them. Table 1 displays a number of descriptive statistics for the population and disease data. The total population was just under 40 million, and lung cancer mortality was four times higher than that of bladder cancer, with the mean number of cases per area being 19 and 4 for lung and bladder cancer, respectively.

Figure 1 depicts the distribution of the smoothed RR: a) for bladder cancer; and b) for lung cancer (both sexes). The patterns of both tumours display similarities as well as differences: the similarities consist of the higher risk found in many of the towns and cities in the Provinces of Cadiz, Huelva and Seville, in Almería, and along the coast of the Valencian Region; the most marked differences correspond to Extremadura, Asturias, and Barcelona Province.

Figures $2 \mathrm{a}$ and $2 \mathrm{~b}$ show the distributions of bladder cancer in men and women. The patterns were different, with less variability in women, yet in both sexes there were 3 large areas, namely, Western Andalusia, Almería and Catalonia.

Shown in Figures $2 \mathrm{c}$ and $2 \mathrm{~d}$ is the distribution of $\mathrm{RR}$ for bladder cancer "adjusted" for distribution of the $\log (\mathrm{RR})$ in lung cancer. This map highlights the differences between the bladder and lung cancer maps. Figures $2 e$ and $2 \mathrm{f}$ "filter" the previous figures, flagging the areas in which excess mortality is more likely.

The towns and cities that registered a risk in excess of 1.30 (Figures 2a and 2b), totalled 101 in men and 36 in women, and belonged, for the most part to the Provinces of Cadiz, Seville, Huelva, Barcelona and Almería. Table 2 shows the results for towns and cities that, with at least 5 observed cases, registered adjusted RR of 1.3 or more and $\mathrm{pp} \geq 0.9$ in men or women.

The highest risk area recorded by Barcelona Province corresponded to very specific municipal areas in the Bages district, e.g., Suría, Sallent, Balsareny, Manresa and Car- 


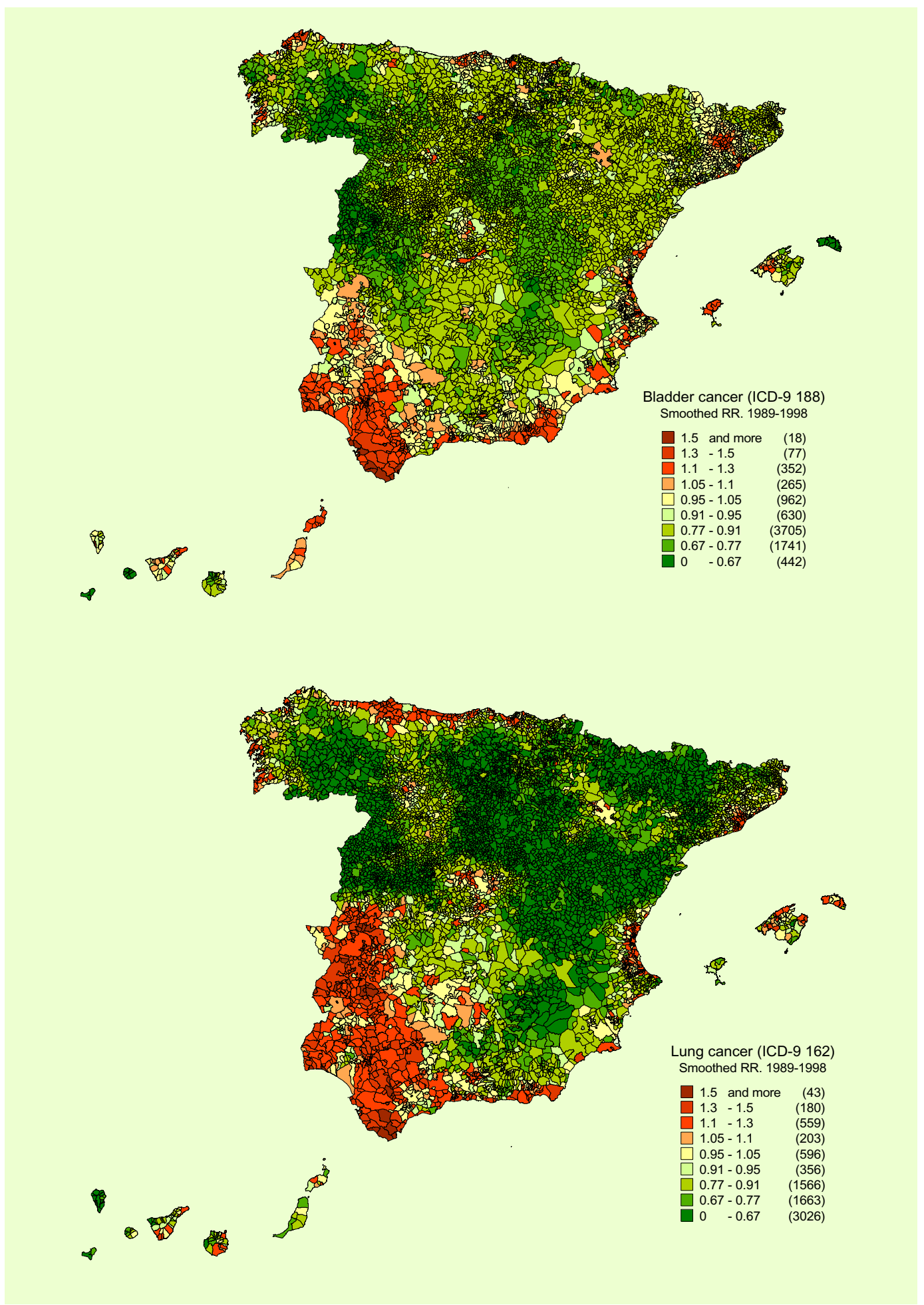

Figure I

Municipal distribution of bladder and lung cancer mortality in Spain. Distribution pattern of smoothed relative risk (RR) under the BYM model. Spain 1989-1998. 

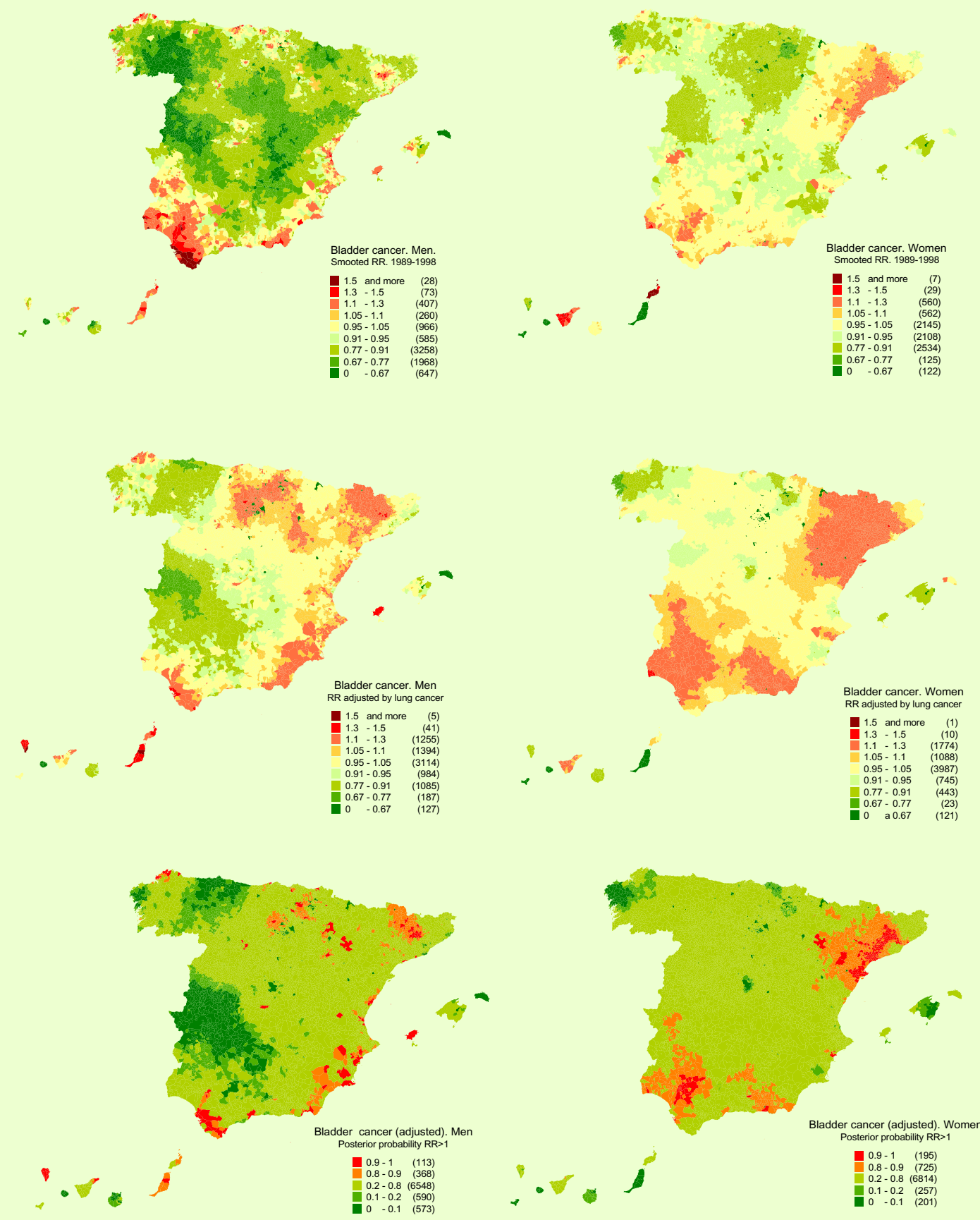

Figure 2

Municipal distribution of bladder cancer mortality: a) men, b) women, c) and d) men and woman respectively adjusted for lung cancer mortality, e) and f) posterior probability of RR being greater than I. Spain 1989-1998. 
Table 2: Bladder cancer mortality in Spain. Towns with 5 or more observed cases, which have shown an RR adjusted for lung cancer of over 1.3 in men or women, with a posterior probability (pp) of over 0.9 that $R R$ is greater than I $(p(R R>I))$. Towns listed in order of province. Spain 1989-1998.

\begin{tabular}{|c|c|c|c|c|c|c|c|c|c|c|c|c|c|c|c|}
\hline \multirow[b]{2}{*}{ NAME } & \multirow[b]{2}{*}{ INE } & \multirow[b]{2}{*}{ Obs } & \multirow[b]{2}{*}{ Exp } & \multicolumn{2}{|c|}{ Both sexes } & \multirow[b]{2}{*}{ PP } & \multirow[b]{2}{*}{ RR adj } & \multicolumn{2}{|l|}{ Men } & \multirow[b]{2}{*}{ RR adj } & \multirow[b]{2}{*}{ Pp adj } & \multicolumn{4}{|c|}{ Women } \\
\hline & & & & SMR & $\mathrm{RR}$ & & & $\mathrm{RR}$ & $\mathrm{PP}$ & & & $\mathrm{RR}$ & PP & RR adj & PP adj \\
\hline EIVISSA & 7026 & 31 & 17.87 & 1.74 & 1.49 & 0.99 & 1.38 & 1.64 & 1.00 & 1.50 & 1.00 & 0.81 & 0.30 & 0.79 & 0.23 \\
\hline SAN JOSE & 7048 & 9 & 7.55 & 1.19 & 1.26 & 0.83 & 1.30 & 1.29 & 0.84 & 1.38 & 0.95 & 0.86 & 0.34 & 0.82 & 0.25 \\
\hline STA EULALIA DEL RIO & 7054 & 16 & 13.18 & 1.21 & 1.23 & 0.85 & 1.33 & 1.26 & 0.87 & 1.39 & 0.96 & 0.86 & 0.33 & 0.81 & 0.25 \\
\hline BALSARENY & 8018 & 9 & 3.82 & 2.35 & 1.41 & 0.96 & 1.38 & 1.48 & 0.96 & 1.38 & 0.98 & 1.13 & 0.76 & 1.23 & 0.89 \\
\hline CARDONA & 8047 & 19 & 7.41 & 2.57 & 1.40 & 0.97 & 1.43 & 1.38 & 0.97 & 1.40 & 0.99 & 1.14 & 0.77 & 1.21 & 0.93 \\
\hline MANRESA & 8113 & 93 & 70.84 & 1.31 & 1.24 & 0.99 & 1.24 & 1.11 & 0.82 & 1.12 & 0.88 & 1.42 & 0.99 & 1.34 & 0.99 \\
\hline MATARO & 8121 & 109 & 77.07 & 1.41 & 1.32 & 1.00 & 1.17 & 1.25 & 0.98 & 1.08 & 0.77 & 1.36 & 0.98 & 1.32 & 0.97 \\
\hline SALLENT & 8191 & 20 & 9.24 & 2.16 & 1.45 & 0.99 & 1.42 & 1.33 & 0.95 & 1.33 & 0.98 & 1.28 & 0.92 & 1.28 & 0.97 \\
\hline SURIA & 8274 & 16 & 6.70 & 2.39 & 1.53 & 0.99 & 1.45 & 1.49 & 0.97 & 1.39 & 0.98 & 1.22 & 0.84 & 1.28 & 0.94 \\
\hline BURGOS & 9059 & 168 & 134.86 & 1.25 & 1.17 & 0.98 & 1.33 & 1.21 & 0.99 & 1.37 & 1.00 & 0.93 & 0.25 & 1.01 & 0.49 \\
\hline ALGECIRAS & 11004 & 109 & 62.39 & 1.75 & 1.71 & 1.00 & 1.25 & 1.89 & 1.00 & 1.33 & 1.00 & 1.00 & 0.51 & 0.99 & 0.45 \\
\hline CADIZ & 11012 & 177 & 97.70 & 1.81 & 1.80 & 1.00 & 1.40 & 1.86 & 1.00 & 1.39 & 1.00 & 1.46 & 0.99 & 1.51 & 0.99 \\
\hline PUERTO DE STA MARIA & 11027 & 70 & 33.62 & 2.08 & 1.90 & 1.00 & 1.43 & 2.08 & 1.00 & 1.49 & 1.00 & 1.08 & 0.67 & 1.12 & 0.77 \\
\hline PUERTO REAL & 11028 & 30 & 15.08 & 1.99 & 1.73 & 1.00 & 1.37 & 1.79 & 1.00 & 1.37 & 0.99 & 1.17 & 0.82 & 1.19 & 0.88 \\
\hline ROTA & 11030 & 27 & 12.55 & 2.15 & 1.83 & 1.00 & 1.38 & 1.97 & 1.00 & 1.45 & 1.00 & 1.08 & 0.64 & 1.12 & 0.71 \\
\hline SAN FERNANDO & 11031 & 74 & 45.04 & 1.64 & 1.63 & 1.00 & 1.39 & 1.60 & 1.00 & 1.34 & 1.00 & 1.42 & 0.97 & 1.39 & 0.98 \\
\hline NARON & 15054 & 38 & 25.05 & 1.52 & 1.35 & 0.98 & 1.32 & 1.35 & 0.97 & 1.31 & 0.98 & 1.07 & 0.60 & 1.00 & 0.45 \\
\hline CARIÑO & $1590 \mid$ & 16 & 6.29 & 2.55 & 1.75 & 0.99 & 1.43 & 1.80 & 0.99 & 1.43 & 0.98 & 1.09 & 0.58 & 1.03 & 0.52 \\
\hline LEPE & 21044 & 14 & 9.72 & 1.44 & 1.38 & 0.95 & 1.06 & 1.29 & 0.89 & 0.99 & 0.44 & 1.30 & 0.81 & 1.33 & 0.91 \\
\hline SOLSONA & 25207 & 14 & 7.48 & 1.87 & 1.34 & 0.89 & 1.44 & 1.26 & 0.82 & 1.37 & 0.95 & 1.22 & 0.76 & 1.28 & 0.87 \\
\hline PUERTO DEL ROSARIO & 35017 & 12 & 6.75 & 1.78 & 1.22 & 0.75 & 1.28 & 1.37 & 0.86 & 1.51 & 0.94 & 0.36 & 0.03 & 0.24 & 0.02 \\
\hline BREÑA BAJA & 38009 & 5 & 3.20 & 1.56 & 1.04 & 0.51 & 1.41 & 1.05 & 0.53 & 1.52 & 0.97 & 0.79 & 0.26 & 0.82 & 0.23 \\
\hline LLANOS DE ARIDANE & 38024 & 21 & 13.83 & 1.52 & 1.15 & 0.75 & 1.53 & 1.23 & 0.84 & 1.68 & 1.00 & 0.75 & 0.22 & 0.80 & 0.20 \\
\hline VILLA DE MAZO & 38053 & 6 & 5.80 & 1.04 & 0.99 & 0.44 & $\mathrm{I} .4 \mathrm{I}$ & 1.01 & 0.48 & 1.53 & 0.98 & 0.78 & 0.26 & 0.83 & 0.23 \\
\hline TOCINA & 41092 & 13 & 6.08 & 2.14 & 1.52 & 0.97 & 1.10 & 1.38 & 0.91 & 1.00 & 0.48 & 1.25 & 0.80 & 1.33 & 0.92 \\
\hline ELIANA & 46116 & 14 & 5.42 & 2.59 & 1.46 & 0.97 & 1.26 & 1.62 & 0.98 & 1.32 & 0.96 & 0.88 & 0.21 & 0.96 & 0.36 \\
\hline
\end{tabular}

$\mathrm{INE}=$ municipal code; Obs $\operatorname{Exp}=$ observed and expected deaths; $\mathrm{RR}=$ estimated relative risk; $S M R=$ standard mortality ratio. $\mathrm{RR}$ adj $=$ estimate adjusted for lung cancer. $\mathrm{PP}=$ posterior probability that $\mathrm{RR}>\mathrm{I}$.

dona. Other towns with relative risks in excess of 1.3 were situated in Murcia, Burgos and Corunna (A Coruña).

Towns in Cadiz, Seville and Huelva registered a certain excess risk for both sexes. In view of the peculiar spatial pattern of these towns, it would seem that there are determinants other than the high prevalence of smokers accounting for the bladder cancer mortality pattern in this area, since this same pattern is also applicable to women. In Almería a sizeable area of raised risk was in evidence.

Barcelona Province was one of the areas that deserve some comments. Two areas of higher risk were identified, one comprising the Bages district (Suria, Sallent, Balsareny, Manresa and Cardona), and the other flanking the coast (Vilanova i la Geltru, Mataró), Barcelona, Barbera, Moncada and Santa Coloma. In the Bages district, excess risk was detected in both sexes: in the case of women, however, not only were the Bages towns identified, but the areas marked on map were also larger. The posterior probability map identifies towns in Vallés, Maresme and Baix
Llobregat and an area in Tarragona around the Delta of the River Ebro.

\section{Discussion}

The municipal geographical bladder cancer pattern is similar to that plotted by lung cancer, possibly reflecting the role of tobacco smoking, the leading etiological agent. The difference in patterns with respect to lung cancer in terms of both geographical distribution and time trend [27] might be attributable to the existence of occupational exposures and environmental differentials. In addition, the differences with other countries in terms of mortality frequency and trend [28] may possibly be related to black tobacco (dark air cured tobacco) use among men, an exposure which, for this tumour, has shown a higher risk than that for other types of tobacco [6].

The origin of bladder cancer is determined by contact between the vesical epithelium and carcinogenic substances excreted in urine. Such substances may be ingested or inhaled directly, or come from the metabolism of other 
products in the body. As mentioned above, the two risk factors acknowledged as being most important for this type of cancer are smoking and occupational exposure to aromatic amines. Among the occupations associated with a higher risk of bladder cancer are those linked to the production of aromatic amines, rubber manufacture, exposure to dyes and printing in the textile industry [7], paint, aluminium, tanning and curing of hides, and the driving of motor vehicles $[6,8]$.

The risk associated with the consumption of chlorinated drinking water was evaluated in different occasions. A recent published metaanalysis indicates that long term consumption of chlorinated drinking water is associated with a $40 \%$ of increased risk of bladder cancer incidence, particularly in men $[14,29]$. Those studies found an increased risk of bladder cancer and a dose-response pattern among men exposed to trihalomethanes at levels currently observed in many industrialized countries. However they did not find an increased risk in women and this observed difference in risk by sex is puzzling.

The municipal mortality pattern shown in Spain needs to include another elements among possible explanations. In the recent years, the role of other environmental exposures, for instance arsenic, in the aetiology of bladder cancer (and other tumours), has gradually become recognised. Inorganic arsenic has been documented as being a skin and lung carcinogen [30,31]. A number of studies have observed a rise in bladder and kidney cancer mortality in populations with high exposure to arsenic in drinking water $[9,10,32,33]$ and, in the case of bladder cancer, a dose-response relationship has been reported $[11,12]$.

The method applied to smooth geographical patterns, with the limitations commented below, is currently the most widely accepted method for data studies focusing on small areas $[2,3]$. One aspect that merits comment is the use of lung cancer mortality as a surrogate variable to adjust for exposure to tobacco. A single aetiological agent, cigarette smoking, is by far the leading cause of lung cancer, accounting for approximately $90 \%$ of lung cancer cases in countries where cigarette smoking is common [34]. Nowadays, the risk of lung cancer posed to smokers is about 20 times greater than that posed to never-smokers [34]. Few exposures to environmental agents convey such risks for any disease. The unequivocal causal association between cigarette smoking and lung cancer is one of the most thoroughly documented causal relationships in biomedical research [34]. Hence, to consider the distribution of lung cancer as a good indicator of the prevalence of smokers is by no means illogical, although this ecological approach is subject to residual confounding.
The joint modelling of several diseases is something that has been addressed on different occasions with varying approaches [35-37]. Recently, two papers have been published on spatial variation in the rates of several diseases with common risk factors, an approach known as "joint disease mapping' [38,39]. Our method of analysis is described as an 'ecological regression' in the paper by Held et al., and in their paper, Dabney et al. provide examples of modelling procedures with lung and bladder cancer incidence.

In our results, the effect of adjusting for lung cancer is to produce a "filtering" of the geographical pattern, extracting from the maps those towns and cities in which bladder cancer mortality can be explained by tobacco use (Figure 2c and 2d).

Most of the municipal areas identified by the models as representing a raised risk for both sexes are situated in the Provinces of Cadiz, Seville and Huelva. On the map adjusted for lung cancer, the towns that are highlighted are listed in order of their proximity to the River Guadalquivir. This, coupled with the fact that this pattern is also seen among women, is indicative that there are environmental components other than the prevalence of smokers underlying bladder cancer mortality in this area. The environs of the Huelva estuary and the Campo de Gibraltar district have been the subject of study and specific reports by the Scientific Research Board (Consejo Superior de Investigaciones Cientificas - CSIC) on the serious situation of their environmental pollution, with high concentrations of heavy metals being detected in sediments throughout the area [40].

The content of these reports [40] and the municipal mortality patterns suggest that industrial activity in the Province of Cadiz, and industrial and mining activity in the Provinces of Seville and Huelva could be associated with bladder cancer mortality in these provinces. Furthermore, bearing in mind the levels of arsenic and other heavy metals in fish and shellfish $[15,41,42]$, questions might well be raised about the possible role played in the incidence of this tumour by the high consumption of fish in Spain [43] and regional differences in such consumption. The maximum limits of arsenic in foodstuffs are still not regulated [40]. In comparison with other European countries, however, Spain has high rates in men only, with bladder cancer in women being extremely infrequent. On the other hand, however, risk of bladder cancer for exposure to low doses of arsenic is reported to have been observed only in smokers $[44,45]$.

In the smoothed maps for Barcelona Province, two areas with higher than expected mortality were detected, one in the Bages district and the other in Vallés, Maresme and 
Baix Llobregat. These two areas differ, in that whereas in the former the risk is higher in both sexes, in the latter this is true only of women (Figures $2 \mathrm{a}$ and $2 \mathrm{~b}$ ).

Wholly different explanations might account for these patterns. The Bages pattern affects men and women, which could be interpreted as due to some environmental exposure other than occupation. The Bages district has been characterised by sodium and potash mining and the textile industry. The mining industry faithfully reflects the towns of Cardona (salt mines worked from 1923 to 1990 by ERCROS), Suria, Sallent, Balsareny (sodium chloride and potash mines, run by Iberpotash). Mining-specifically salt mining [8] - is one of the occupations in which an association has been described with bladder cancer. High concentrations of arsenic have been detected in the Cardener and Llobregat Rivers, concentrations that have clearly increased due to the influence of the mining activity in Sallent-Balsareny [46]. Moreover, in the 1930s the Bages district and Llobregat basin were the leading cottonbased textile industry areas in Catalonia [47].

The Vallés/Maresme pattern, which is only observable in women, might be related to the textile industry traditionally situated in these areas. Textiles, particularly cotton, constituted the strongest sector by far in Catalonian industrialisation, a sector characterised by an abundant presence of women workers. Dyeing and printing are the sections that have shown an association with bladder cancer in the literature [7]. Posterior studies conducted in Barcelona province do not support the findings respective to the textile industry although they found very high relative risks in workers employed for very long [48]. In a pooled analysis of occupation and bladder cancer in women, the increased risk in textile industry is for exposed for more than 25 years [49]. In a more recent update the opinion is that there is a general tendency to move toward unity for all the cancer relative risk estimates in textile industry workers [50]. Some exposures to carcinogens could be limited in time, with the improving of industrial procedures.

Some authors have described an association between arsenic levels in drinking water and the incidence of certain tumours, including transitional cell carcinomas of the urinary bladder [51]. It could be argued that maximum levels of arsenic in drinking water are limited by law and are routinely monitored, so that any substantial excess risk would be difficult to explain. Nevertheless, the limit on arsenic levels in water is currently under discussion. Until 1990 the maximum permissible level in Spain of arsenic intended for human consumption was $100 \mu \mathrm{g} / \mathrm{l}$. This was then reduced to $50 \mu \mathrm{g} / \mathrm{l}$. Subsequently, the European Council Directive 98/83/EC of 3 November 1998 on the quality of water intended for human consumption, applied the World Health Organisation (WHO) guideline and set the maximum admissible concentration for this element at $10 \mu \mathrm{g} / \mathrm{l}$, the level adopted in Spain at the end of 2003 (Royal Decree 140/2003). These data not only attest to the controversy surrounding the health risk of ingesting inorganic arsenic and the advisability of present and future limits [52,53], but also mean that for many years the permitted levels of arsenic in drinking water have been up to 10 times higher than those now tolerated. The hypothesis of exposure to arsenic would be reinforced, if the proportion of the population that drinks well-water and is thus more difficult to control, were higher in areas with higher risks of bladder cancer, but this is something that we do not know.

The use of arsenic-based pesticides has been viewed as the principal source of arsenic-related environmental pollution in recent decades [17]. Phytosanitary products are used intensively in areas like Almería, a factor that calls for detailed study.

Arsenic can also been found in certain pesticides and in wood preservatives. In the past, arsenic was primarily used as a pesticide, primarily on cotton fields and in orchards. Inorganic arsenic compounds can no longer be used in agriculture. However, organic arsenicals, namely cacodylic acid, disodium methylarsenate (DSMA), and monosodium methylarsenate (MSMA) are still used as pesticides, principally on cotton [54].

Andalusia holds almost 95\% of cotton cultivated surface, which represents $2 \%$ of its cropland. Cotton crops are mainly found in Occidental Andalusia (Seville, Cadiz, Cordoba), in the region known as "Bajo Guadalquivir", and to a much lesser extent, in Huelva. In "Bajo Guadalquivir" other usual crops are sunflower, beetroot and cereals such as rice, in which pesticide use has also been quite common.

Another possible source of arsenic might be occupational exposure to chromated copper arsenate (CCA), which is an inorganic arsenic compound commonly used as wood preservative for outdoor furnitures $[55,56]$. The marketing and use of this substance (CCA) as wood preservant and the commercialization of the products treated with it has been recently banned (COMMISSION DIRECTIVE 2003/ 2/ES january 6, 2003).

Geographical small-area studies such as ours, though targeted at generating aetiological hypotheses, can be efficient instruments for detecting problems connected with environmental quality and, in addition, furnish very flexible information which enables some of the limitations posed by classic ecological studies to be overcome. The results suggest that mining/industrial pollution and the 
risk entailed in certain occupational exposures could in part be dictating the pattern of municipal bladder cancer mortality in Spain. Population exposure to arsenic found in diet and drinking water is a matter that calls for attention. Accordingly, it would seem advisable to study the possible restriction of inorganic arsenic levels in foods and to explore whether some relationship exists between the chemical quality of drinking water and the frequency of bladder cancer in Spain. Also the use of arsenical pesticides deserve attention in Occidental Andalucía and Almería.

\section{Competing interests}

The author(s) declare that they have no competing interests.

\section{Authors' contributions}

GLA was responsible for the development of intellectual content and the study design, interpretation of the results and manuscript drafting. MP, NA, BPG contributed with the study design, the improving of mortality modelling and the critical revision of manuscript. AE contributed in the critical review of results and discussion. RR, VH performed part of the statistical analysis and contributed to manuscript drafting. All authors read and approved the final manuscript.

\section{Acknowledgements}

This study was financed by Grant No. EPY-I I 76/02 from the Carlos III Institute of Health (ISCIII) and RCESP FIS-C03/09 (Spanish Network for Cooperative Research in Epidemiology and Public Health).

\section{References}

I. Coleman MP, Gatta G, Verdecchia A, Esteve J, Sant M, Storm H, Allemani C, Ciccolallo L, Santaquilani M, Berrino F: EUROCARE-3 summary: cancer survival in Europe at the end of the 20th century. Ann Oncol 2003, I4(Suppl 5):v|28-v|49.

2. Lawson A, Biggeri A, Bohning D, Lesaffre E, Biggeri A, Viel JF, et al:: Disease mapping and risk assessment for public health Chichester: Wiley; 1999.

3. Elliott P, Wakefield JC, Best N, Briggs S: Spatial epidemiology New York: Oxford; 2000.

4. Richardson S, Thomson A, Best N, Elliott P: Interpreting posterior relative risk estimates in disease-mapping studies. Environ Health Perspect 2004, I I 2:1016-1025.

5. Lopez-Abente G, Gonzalez CA, Errezola M, Escolar A, Izarzugaza I, Nebot M, Riboli E: Tobacco smoke inhalation pattern, tobacco type, and bladder cancer in Spain. Am J Epidemiol I99I, 134:830-839.

6. Silverman DT, Hartge P, Morrison AS, Devesa SS: Epidemiology of bladder cancer. Hematol Oncol Clin North Am 1992, 6: I-30.

7. Gonzalez CA, Lopez-Abente G, Errezola M, Escolar A, Riboli E, Izarzugaza I, Nebot M: Occupation and bladder cancer in Spain: a multi-centre case-control study. Int J Epidemiol 1989, 18:569-577.

8. Kogevinas M, Mannetje A., Cordier S, Ranft U, Gonzalez CA, Vineis $P$, Chang-Claude J, Lynge E, Wahrendorf J, Tzonou A, Jockel KH, Serra C, Porru S, Hours M, Greiser E, Boffetta P: Occupation and bladder cancer among men in Western Europe. Cancer Causes Control 2003, I4:907-9|4.

9. Chen CJ, Chuang YC, You SL, Lin TM, Wu HY: A retrospective study on malignant neoplasms of bladder, lung and liver in blackfoot disease endemic area in Taiwan. Br J Cancer 1986, 53:399-405.
10. Smith $A H$, Goycolea M, Haque R, Biggs ML: Marked increase in bladder and lung cancer mortality in a region of Northern Chile due to arsenic in drinking water. Am J Epidemiol 1998, | 47:660-669.

II. Chiou HY, Hsueh YM, Liaw KF, Horng SF, Chiang MH, Pu YS, Lin JS, Huang $\mathrm{CH}$, Chen $\mathrm{C}$ ): Incidence of internal cancers and ingested inorganic arsenic: a seven-year follow-up study in Taiwan. Cancer Res 1995, 55: 1296-1300.

12. Tsuda T, Babazono A, Yamamoto E, Kurumatani N, Mino Y, Ogawa $\mathrm{T}$, Kishi $\mathrm{Y}$, Aoyama H: Ingested arsenic and internal cancer: a historical cohort study followed for 33 years. Am J Epidemiol 1995, 141:198-209.

13. Hopenhayn-Rich C, Biggs ML, Smith AH: Lung and kidney cancer mortality associated with arsenic in drinking water in Cordoba, Argentina. Int J Epidemiol 1998, 27:56I-569.

14. Villanueva CM, Cantor KP, Cordier S, Jaakkola J], King WD, Lynch CF, Porru S, Kogevinas M: Disinfection byproducts and bladder cancer: a pooled analysis. Epidemiology 2004, 15:357-367.

15. Llobet JM, Falco G, Casas C, Teixido A, Domingo JL: Concentrations of arsenic, cadmium, mercury, and lead in common foods and estimated daily intake by children, adolescents, adults, and seniors of Catalonia, Spain. J Agric Food Chem 2003, $5 \mathrm{I}: 838-842$.

16. Bordajandi LR, Gomez G, Abad E, Rivera J, Mar Fernandez-Baston M, Blasco J, Gonzalez MJ: Survey of persistent organochlorine contaminants (PCBs, PCDD/Fs, and PAHs), heavy metals ( $\mathrm{Cu}$, $\mathrm{Cd}, \mathrm{Zn}, \mathrm{Pb}$, and $\mathrm{Hg}$ ), and arsenic in food samples from Huelva (Spain): levels and health implications. J Agric Food Chem 2004, 52:992-100I.

17. Urieta I, Jalon M, Eguilero I: Food surveillance in the Basque Country (Spain). II. Estimation of the dietary intake of organochlorine pesticides, heavy metals, arsenic, aflatoxin MI, iron and zinc through the Total Diet Study, 1990/9 I. Food Addit Contam 1996, 13:29-52.

18. Delgado-Andrade C, Navarro M, Lopez H, Lopez MC: Determination of total arsenic levels by hydride generation atomic absorption spectrometry in foods from south-east Spain: estimation of daily dietary intake. Food Addit Contam 2003, 20:923-932.

19. Herce-Pagliai C, Moreno I, Gonzalez G, Repetto M, Camean AM: Determination of total arsenic, inorganic and organic arsenic species in wine. Food Addit Contam 2002, 19:542-546.

20. Michaud DS, Wright ME, Cantor KP, Taylor PR, Virtamo J, Albanes D: Arsenic concentrations in prediagnostic toenails and the risk of bladder cancer in a cohort study of male smokers. Am J Epidemiol 2004, 160:853-859.

21. Clayton D, Kaldor J: Empirical Bayes estimates of age-standardized relative risks for use in disease mapping. Biometrics 1987, 43:67I-68I.

22. Besag J, York J, Molliè A, Besag J, York JC, Mollie A: Bayesian image restoration, with two applications in spatial statistics (with discussion). Annals of the Institute of Statistical Mathematics 1991, 43: $1-59$.

23. Clayton DG, Bernardinelli L, Montomoli C: Spatial correlation in ecological analysis. Int J Epidemiol 1993, 22: I | 93-1202.

24. Gilks W, Richardson S, Spiegelhalter D: Markov Chain Monte Carlo in Practice. Interdisciplinary Statistics Boca Raton, Florida: Chapman \& Hall/ CRC; 1995.

25. Spiegelhalter D, Thomas A, Best N, Lunn D: WinBUGS user manual. Version I.4.I Cambridge: MRC; 2003.

26. Smith BJ: Bayesian Output Analysis Program (BOA), Version 0.99.1 for S-PLUS and R. 200I [http://www.publichealth.uiowa.edu/BOA]. Ref Type: Internet Communication

27. Lopez-Abente G, Pollán M, Aragones N, Pérez B, Llácer A, Pérez J, et al.: Tendencias de la mortalidad en España, 1952-1996. Efecto de la edad, de la cohorte de nacimiento y del periodo de muerte Madrid: Instituto de Salud Carlos III; 2002.

28. Ferlay J, Bray F, Sankila R, Parkin D: EUCAN: Cancer Incidence, Mortality and Prevalence in the European Union 1998, version 5.0 Lyon; 1999.

29. Villanueva CM, Fernandez F, Malats N, Grimalt JO, Kogevinas M: Meta-analysis of studies on individual consumption of chlorinated drinking water and bladder cancer. J Epidemiol Community Health 2003, 57: 166-173.

30. IARC (International Agency for Research on Cancer): IARC monographs on the evaluation of carcinogenic risks to humans: overall evalua- 
tions of carcinogenicity. An updating of IARC monographs volumes I to 42 Lyon: International Agency for Research on Cancer; 1987.

31. EPA (Environmental Protection Agency): Risk assessment forum. Special report on ingested inorganic arsenic: skin cancer, nutrition essentiality Washington, DC: Environmental Protection Agency; 1988.

32. Wu MM, Kuo TL, Hwang YH, Chen CJ: Dose-response relation between arsenic concentration in well water and mortality from cancers and vascular diseases. Am J Epidemiol 1989, 130:1 I23-1132.

33. Hopenhayn-Rich C, Biggs ML, Fuchs A, Bergoglio R, Tello EE, Nicolli $\mathrm{H}$, Smith $\mathrm{AH}$ : Bladder cancer mortality associated with arsenic in drinking water in Argentina. Epidemiology 1996, 7: I 17-124.

34. Alberg AJ, Samet JM: Epidemiology of lung cancer. Chest 2003, 123:2 IS-49S.

35. Langford IH, Leyland AH, Rasbash J, Goldstein $\mathrm{H}$ : Multilevel modelling of the geographical distributions of diseases. J $R$ Stat Soc Ser C Appl Stat 1999, 48:253-268.

36. Leyland AH, Langford IH, Rasbash J, Goldstein $\mathrm{H}$ : Multivariate spatial models for event data. Stat Med 2000, 19:2469-2478.

37. Knorr-Held L, Best N: A shared component model for detecting joint and selective clustering of two diseases. Journal of the Royal Statistical Society, Series A 2001, 164:73-86.

38. Held L, Natario I, Fenton SE, Rue H, Becker N: Towards joint disease mapping. Stat Methods Med Res 2005, 14:6I-82.

39. Dabney AR, Wakefield JC: Issues in the mapping of two diseases. Stat Methods Med Res 2005, 14:83-II2.

40. CSIC (Consejo Superior de Investigaciones Científicas): Informes del estudio sobre el diagnóstico ambiental y sanitario de la ría de Huelva. Segundo informe del estudio que coordina el Consejo Superior de Investigaciones Científicas sobre el diagnóstico ambiental y sanitario de la ría de Huelva. 2005 [http://www.csic.es/wi/informes csic.jsp]

41. Sanzo JM, Dorronsoro M, Amiano P, Amurrio A, Aguinagalde FX, Azpiri MA: Estimation and validation of mercury intake associated with fish consumption in an EPIC cohort of Spain. Public Health Nutr 200I, 4:98I-988.

42. Schuhmacher M, Batiste J, Bosque MA, Domingo JL, Corbella J: Mercury concentrations in marine species from the coastal area of Tarragona Province, Spain. Dietary intake of mercury through fish and seafood consumption. Sci Total Environ 1994 I 56:269-273.

43. Welch AA, Lund E, Amiano P, Dorronsoro M, Brustad M, Kumle M, Rodriguez M, Lasheras C, Janzon L, Jansson J, Luben R, Spencer EA, Overvad K, Tjonneland A, Clavel-Chapelon F, Linseisen J, KlipsteinGrobusch K, Benetou V, Zavitsanos X, Tumino R, Galasso R, BuenoDe-Mesquita HB, Ocke MC, Charrondiere UR, Slimani N: Variability of fish consumption within the 10 European countries participating in the European Investigation into Cancer and Nutrition (EPIC) study. Public Health Nutr 2002, 5: I 273-I 285.

44. Karagas MR, Tosteson TD, Morris JS, Demidenko E, Mott LA, Heaney J. Schned A: Incidence of transitional cell carcinoma of the bladder and arsenic exposure in New Hampshire. Cancer Causes Control 2004, 1 5:465-472.

45. Bates MN, Rey OA, Biggs ML, Hopenhayn C, Moore LE, Kalman D, Steinmaus C, Smith AH: Case-control study of bladder cancer and exposure to arsenic in Argentina. Am J Epidemiol 2004, 1 59:38|-389.

46. Rosas Rodríguez $\mathrm{H}$ : Estudio de la contaminación por metales pesados en la cuenca del Llobregat. Doctoral thesis. 200I [http://www.tdx.cesca.es/ TDX-07/2101-075103/].

47. Nadal J: Moler, tejer y fundir. Estudios de historia industrial Barcelona: Ariel; 1992.

48. Serra C, Bonfill $X$, Sunyer J, Urrutia G, Turuguet D, Bastus R, Roque $M$, 't MA, Kogevinas M: Bladder cancer in the textile industry. Scand J Work Environ Health 2000, 26:476-48I.

49. Mannetje A, Kogevinas M, Chang-Claude J, Cordier S, Gonzalez CA Hours M, Jockel KH, Bolm-Audorff U, Lynge E, Porru S, Donato F, Ranft U, Serra C, Tzonou A, Vineis P, Wahrendorf J, Boffetta P: Occupation and bladder cancer in European women. Cancer Causes Control 1999, 10:209-217.

50. Mastrangelo G, Fedeli U, Fadda E, Milan G, Lange JH: Epidemiologic evidence of cancer risk in textile industry workers: a review and update. Toxicol Ind Health 2002, 18:171-181.

51. Luster MI, Simeonova PP: Arsenic and urinary bladder cell proliferation. Toxicol Appl Pharmacol 2004, 198:419-423.
52. Aragones SN, Palacios DM, Avello dM, Gomez RP, Martinez CM, Rodriguez Bernabeu MJ: [Arsenic levels in drinking water supplies from underground sources in the community of Madrid]. Rev Esp Salud Publica 200I, 75:42I-432.

53. Smith AH, Lopipero PA, Bates MN, Steinmaus CM: Public health. Arsenic epidemiology and drinking water standards. Science 2002, 296:2|45-2|46.

54. ATDSR: Public Health Statement for Arsenic CAS\# 7440-382. 2000 [http://www.atsdr.cdc.gov/toxprofiles/phs2.html]. Consulted on June 2005

55. Edlich RF, Winters KL, Long WB III: Treated wood preservatives linked to aquatic damage, human illness, and death - a societal problem. J Long Term Eff Med Implants 2005, I 5:209-223.

56. Belluck DA, Benjamin SL, Baveye P, Sampson J, Johnson B: Widespread arsenic contamination of soils in residential areas and public spaces: an emerging regulatory or medical crisis? Int J Toxicol 2003, 22:109-128.

\section{Pre-publication history}

The pre-publication history for this paper can be accessed here:

http://www.biomedcentral.com/1471-2458/6/17/prepub

Publish with BioMed Central and every scientist can read your work free of charge

"BioMed Central will be the most significant development for disseminating the results of biomedical research in our lifetime. "

Sir Paul Nurse, Cancer Research UK

Your research papers will be:

- available free of charge to the entire biomedical community

- peer reviewed and published immediately upon acceptance

- cited in PubMed and archived on PubMed Central

- yours - you keep the copyright
BioMedcentral 